DOI: 10.2478 /ausp-2020-0016

\title{
Code Play as Translingual Practice
}

\author{
Enikő BIRÓ \\ Sapientia Hungarian University of Transylvania (Cluj-Napoca, Romania) \\ Department of Applied Linguistics, Târgu-Mureş \\ biro.eniko@ms.sapientia.ro
}

\begin{abstract}
The study starts with the definition of local, translocal, and global linguistic context in the digital space. Facebook as a social media platform provides opportunities for everyday digital literacy practices such as code play. Code play allows mixing codes and repertoires usually with a humorous reference. We argue that creative interaction among languages creates the methodological need for a translingual approach besides the traditional code-switching theory to explain online linguistic phenomena. Adopting a netnographic approach, this paper presents two participants' linguistic history, online linguistic practices, and perceptions of their own digital literacy, exploring their portrayal of (multi)linguistic identity which has local, translocal, and global resonance. The paper exploits possibilities of code play to accomplish communicative goals through code-switching and translingualism with a linguistically diverse audience.
\end{abstract}

Keywords: online linguistic practices, code play, code-switching, translingualism

\section{Introduction}

The purpose of this paper is to examine linguistic practices and semiotic resources on Facebook through the theoretical concepts of code-switching and translingualism. Social media platforms present endless opportunities for digital literacy practices around the world (de Bres 2015). In order to approach these practices, netnography (or online ethnography) has been chosen to reveal two bilingual social media users' linguistic history, online linguistic practices, and perceptions of their own digital literacy, exploring their portrayal of (multi)linguistic identity, which has local, translocal, and global resonance. The paper focuses on the analysis of code play through code-switching and translingualism.

Code play, a linguistic phenomenon, also present in the social media, allows mixing codes and repertoires, usually with a humorous reference. "Hybrid and playful deployment of linguistic resources on the Internet, or digital code play, 
allow writers to display not only their linguistic competence and metalinguistic awareness, but also their multivocal identities" (Lee 2016: 65). While language choices and practices construct identity, humour in code play creates nodes for the individual within the local, translocal, or global context. Humour bridges the gap between various languages and cultures. Examples of digital creativity, such as code play, can be seen as "non-elite and non-institutionalized practices" (Thurlow 2012: 186).

A linguistically diverse audience requires the definition of local, translocal, and global linguistic context in the digital space, which represents the starting point of this research. Then, it is argued that in the digital space creative interaction among languages creates the methodological need for a translingual approach to these linguistic phenomena besides the more traditional code-switching theory. Finally, code play, as an online linguistic practice is presented and data collection with the help of netnography is described, together with the analysis of the data. Patterns of code play are analysed in two case studies as empirical inquiries that investigate the role of linguistic practices in real-life digital context. The research questions also focus on possible shifts from monolingual repertoire towards a multilingual one in the digital space.

\section{Local, translocal, and global as linguistic framework}

The Internet has become a space where individuals share their interests, news, etc., and these individuals may come from different social, ethnic, or linguistic backgrounds. The net, as a translocal space, is a linguistic contact zone now, "in which multilingual resources and repertoires can turn out to be crucial capital for successful communication, action and interaction” (Leppänen-Peuronen 2012: 389). Therefore, research focus is no longer on the measuring of particular languages on the Internet but on multilingual practices of users and their language choices. Facebook, being a social media platform, has emerged as a globalized and translocal site where both verbal and visual contents are posted by the users and shared globally, with local references. "Digital media have afforded important translocal and transnational spaces for people to engage in new kinds of communicative practices and linguistic resources. These new practices also enable online participants to assert new kinds of local and global identities" (Lee 2016: 57). Users participate in the global space through English (even if their knowledge of English is a limited one) without giving up their local identities and local languages (Lee 2016).

However, users have a choice to share their ethnic identities with the public by using linguistic or semiotic resources. For example, Facebook content may include national symbols. The hussar costume (Figure 1) and the intertextuality - a quote from a well-known Hungarian folk song ("Akkor szép a huszár, ha felül a lovára..." 
'Handsome is the hussar, riding his horse...']) - have a symbolic reference and emphasize the user's Hungarian linguistic identity.

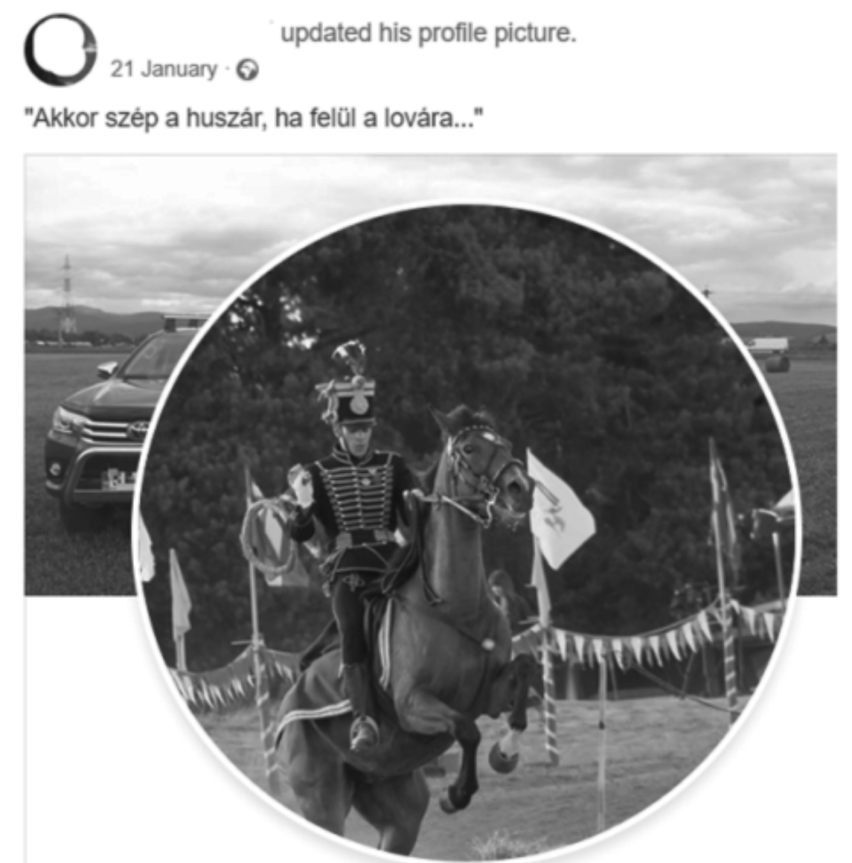

Figure 1. Hungarian symbols and local identity

The choice of language(s) is related to the wish of the users to project themselves as global or local members (Lee 2016). Using multiple languages creates a wider audience group for the user and transforms the social media platform into a diverse tool of communication, and at the same time you can reach out to many people (expressed by Participant A, during the interview). The use of a single (particularly a minority) language, while online, narrows the audience. Monolingual practices clearly outline a local linguistic identity; however, Facebook affords translocal opportunities, thus the possibility to connect the global and multilingual world to local references. According to Blommaert, englobalization and deglobalization are present, where englobalization refers to the global circulation of resources, and deglobalization means that globally circulated resources are locally reappropriated with new local meanings (Blommaert-Rampton 2011). Hashtags and captions used with a global meme or any globally widespread semiotic resource are connected with a local meaning. For example, the abundance of hashtags (Figure 2) includes well-known semiotic references and promotes the local event to a global level: a student party in a Romanian town leaves behind its local context and emerges to a global one. 


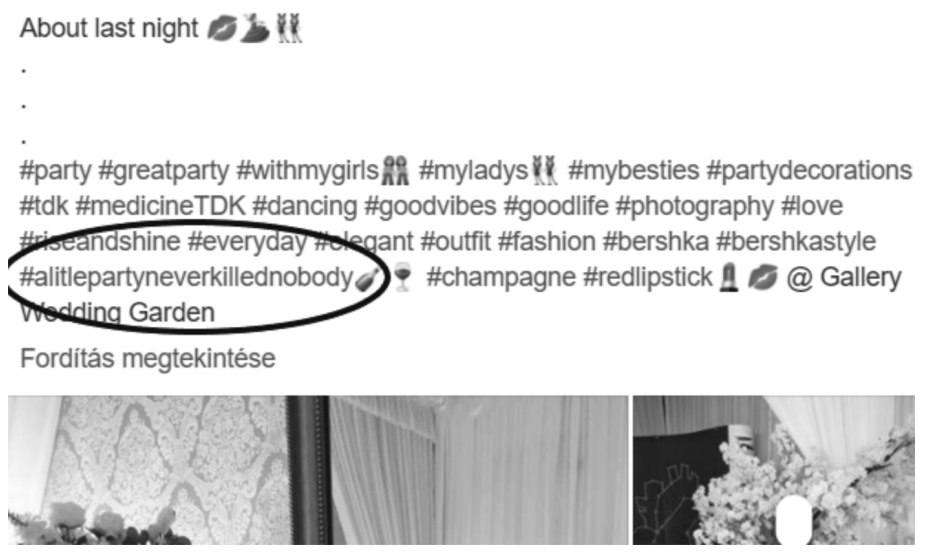

Figure 2. Hashtags as code play with global reference

Intertextuality as a semiotic resource, embedding the title of the song $A$ Little Party Never Killed Nobody, facilitates the user to claim global identity.

\section{Online code-switching and translanguaging as conceptual framework: Code play re-defined}

There is a need to challenge the traditional concepts of multilingualism and codeswitching, which have become major focuses of contemporary sociolinguistics (Pennycook 2016), when online linguistic diversity proves to be more than a mix of language systems (Androutsopoulos 2007, Dovchin-Pennycook 2018); and, moreover, it is associated with creativity, i.e. the use of different semiotic resources. In the light of this phenomenon, Facebook becomes a transmodal digital space (Sharma 2012), where English and other languages are mixed and draw on both local and global media content. As Leppänen et al. point it out, this means "superdiversity" in social media, generated by "the mobility and mobilization of linguistic and other semiotic resources that are distributed, recontextualized and resemiotized in various ways in countless and rhizomatic digital media practices mushrooming on the internet” (Leppänen et al. 2015: 4). It seems that traditional and widespread notions of bi- and multilingualism, as well as code-switching, fall short in addressing the online mixed linguistic repertoires, which combine digital linguistic and semiotic practices in a fluid way. Code-switching usually refers to the alternation of codes, or the alternation between languages, and it is controlled by the speakers due to interactional rules. Code-switching is a salient linguistic practice in the digital social media; however, the multilingual Internet provides more interesting linguistic questions than the investigation into which language dominates or how code-switching happens. In the digital space, any user can 
experience or do things with multiple languages - the question is "how people take up new possibilities offered by the different languages on the web" (Lee 2016: 126). Although addressed to a specific audience group, mono- or multilingual comments, shares, etc. are available to the wide public (who is not involved directly in the conversation), connecting local content with a global space. Therefore, this process can be seen "as a kind of translingual practice which emphasizes the process of working with different languages rather than the product and which focuses on communicative practices across groups and communities rather than within a specific speech community defined primarily by the geographical locations of speakers" (Lee 2016: 126).

The concept of translanguaging was first used by Cen Williams in $1994^{1}$ to refer to a pedagogical practice where languages are used alternatively for educational purposes. However, since then, the term translanguaging has been increasingly used to refer to complex and fluid language practices of multilinguals as well. A new perspective was born with the speaker in focus and not the languages per se. If the analytical focus is on how language users exploit all linguistic, semiotic resources to create meaning, then translanguaging is the term to be looked for. Moreover, translanguaging defines language as a multimodal, multisensory sense- and meaningmaking resource. In doing so, it seeks to challenge boundaries: boundaries between named languages, boundaries between the so-called linguistic, paralinguistic, and non-linguistic means of communication, and boundaries between language and other human cognitive capacities (Li 2016). As a conceptual framework, translanguaging is seen as an approach that considers the language practices of bilinguals or multilinguals, where language systems are not separated. Its focus is on the linguistic repertoire with features that have been societally constructed (García-Li 2014: 2). While the term code-switching is seen as a binary operation and indicates the presence of several languages, the concept of translingualism emphasizes creative interaction between languages. According to Canagarajah, there is a need to look at translingual practices where communication transcends both "individual languages" and words, thus involving "diverse semiotic resources and ecological affordances" (Canagarajah 2013: 6).

Online users deploy their linguistic resources for the sake of creativity and playfulness: with languages, orthographies, typographies, and these practices or code plays may emphasize and represent their bi- or multilingual identities or simply create their new identities online. These practices may present them as local members of a certain group (online or offline), may provide translocal opportunities, connecting them to the global community, or may introduce them as genuine cosmopolitan citizens (Peuronen 2011). There are two important factors characterizing code plays. First, “an immediate effect often presented by playful

1 The term was created by Cen Williams in his 1994 unpublished thesis An Evaluation of Teaching and Learning Methods in the Context of Bilingual Secondary Education. 
alternations of codes is humor” (Lee 2016: 64), and, second, these digital code plays violate expectations of code-switching in speech. Code play in this sense becomes part of a hybrid and multimodal style that combines linguistic practices, which "give rise to new forms of translingual and translocal encounters across cultures" (Lee 2016: 66). In terms of code play, both approaches, i.e. code-switching and translanguaging, can definitely add significant values to their understanding. If code play is carried out in order to provide a humorous reference, then code-switching is the right term to be used for the research framework. However, if code play is practised in order to maximize or to ease the communicative process, then we are in need of a different research framework offered by translingualism. This means that language users exploit all linguistic and semiotic resources to create meaning.

Ultimately, whatever concept is used to describe these digital practices online, unprecedented opportunities are being experienced regarding the use of multilingual repertoires from code-switching to translingual practices. Minority languages have their own localized space in the online social media and through translingual practices find their own way to a global display.

\section{Linguistic netnography as research framework and data collection}

This paper looks at the online linguistic practices of two bilingual (HungarianRomanian) university students at Sapientia Hungarian University of Transylvania (henceforth: Sapientia) in Romania. The research was conducted from March to May 2020, and the results were completed with the description of the participants' offline linguistic practices and identities revealed by metadiscourses from interviews. Data collection follows the research framework of "linguistic netnography" (Kozinets 2006) - also named as "Internet/online ethnography" (Androutsopoulos 2006) - in order to observe and look into the online literacy practices. Linguistic netnography is a qualitative research method that adopts ethnographic research techniques in examining the culture of online communities, emerging through computer-mediated communications, which includes systematic observation of online activities, collection and linguistic analysis of screen data, and additional data elicited through contact with users. Methods may include semiotic, visual, or content analysis, participant and non-participant observations as well as interviews.

Data collection started with the selection of participants, who served as case studies in the present research. Two research participants were selected for the purpose of the study, which provided the linguistic data for an in-depth, thorough analysis for the present research. These participants provided impressive multilingual Facebook entries worth collecting and analysing as linguistic data. After obtaining permission to use their personal data (according to GDPR consent requirements), the 
observation of three months online Facebook entries followed, i.e. screenshots were taken in order to collect, categorize, and analyse the linguistic data. This approach gives access to observe the participants' language practices and "to learn about their offline practices through the online linguistic and cultural resources" (DovchinPennycook 2018: 215) which build up their linguistic repertoire. Finally, the research participants were invited for interviews and casual discussions (online) in terms of their own metalinguistic interpretations. They also provided some insights about their social and cultural backgrounds, issues about their language use and identity constructions. The questions of the interviews were divided into two main parts. First, the questions referred to the offline linguistic and family background of the participants, completed with inquires about their offline linguistic practices, language use, and choice. Second, the questions referred to the selected, categorized screenshots. These inquiries highlighted multilinguistic practices of each participant, and they were asked to explain the choice of languages, while they also reflected on their multilingual practices. The interviews were recorded, and the metalinguistic data were processed at a later moment. This research, therefore, combines aspects of linguistic and online ethnography - which is termed linguistic netnography - to explore code-switching and translingual practices of participants.

The participants' names for the present study are pseudonyms to provide anonymity. Throughout this paper, the term first language (L1) is used to refer to Hungarian as the language "best known and/or most used" by the participants and the language they self-identified with as the "native language" or "mother tongue" (Skutnabb-Kangasand-McCarty 2008: 6). L2, the second language, is Romanian. Research participants have learnt English as a foreign language; therefore, L3 refers to English throughout this paper. Both participants have learnt further languages such as German, French, Spanish, or even some Greek; therefore, their attitude towards language learning is very positive, revealed by the interview data as well. All Hungarian and Romanian data texts, including the interview accounts used in the data examples of this paper, have been translated from Hungarian and Romanian into English by the researcher.

\section{Data analysis: Code play, code-switching, and translanguaging}

\subsection{Participant A: Adam}

Participant A's (reference name: Adam, male, Sapientia $1^{\text {st }}$-year student, majoring in translation-interpreting) online code-switching and translingual practices on Facebook mainly concern the relocalization of English and other semiotic resources integrated within Hungarian and Romanian local context. His literacy practices 
also point to offline aspects of his linguistic identity. In offline linguistic situations, Adam switches codes in order to communicate with the members of his family. He uses Hungarian with his parents but switches to Romanian with his aunt, who is Romanian and lives next to them. He is a bilingual; however, he mixes English or even Spanish words with Hungarian ones, constructing his multilingual identity offline as well. Adam's presence on Facebook is intense, and his feed is largely composed of multimodal and multi-semiotic resources, including reposts of YouTube songs, memes, local and global news.

His mother tongue (L1) is Hungarian, and he belongs to the Hungarian ethnic minority living in Romania, in a small town. The population of this town is mixed, with almost 50-50 per cent Romanians and Hungarians living there. His parents are Hungarian; he lives in an extended family, where his aunt is Romanian, and therefore he has learnt Romanian from a very early age. He studied in Hungarianmedium schools; however, his accent and choice of words show the influence of L2, Romanian. Nevertheless, he shows a very open attitude towards languages and language learning as he has been learning languages since early childhood. He also considers English, L3, his second mother tongue; he continuously reads in English, watches TV-series, and uses English as a lingua franca in multiplayer video games. During the interview, he often mixes English words and expressions with Hungarian ones - this code-switching is obviously used to create a unique style and to show off with his knowledge: Mindent megértek, ha nem ilyen technobabble 'I can understand everything if it is not a so-called techno-babble', or he expresses that knowing English helps him in many communicative situations: Mert az mindig a safety pillow 'Because it is always the safety pillow'. Besides English, he used to learn German and French in school, and he tried to pick up some Spanish from telenovelas (soap operas). He has also learnt a few words in Greek (interested in mythology), Finnish, Portuguese, and some Romani. During the interview, he immediately demonstrates his knowledge by enunciating a few examples. He considers language learning as an easy and stimulating task and plans to learn Japanese at a certain moment in the future, being very interested in anime cartoons as he often watches them. He also believes that all languages have a certain musicality: akkor is, ha csak a fejedben olvasod ki a szavakat, sokkal színesebb lesz az a megosztás 'even if you just read the words in your head, that multilingual Facebook post becomes much more colourful'.

\subsubsection{Adam's choice of languages online: "You need a certain language to express an idea in the most beautiful way"}

In the online world, he chooses English over Hungarian when possible, also because Hungarian spelling is complex and means sluggish typing for him. The default language of his Facebook account is English. He uses Facebook to read and 
share memes, jokes, or fun facts. However, it is important for him to share or post content in Hungarian in order to reach out to the majority of his friends, who are Hungarians. Simple English texts are shared without any adaptation because if the message is better conveyed in the original language, then it should not be translated, as he conveys: néha egy gondolatot egy adott nyelven lehet a legszebben kifejezni 'sometimes an idea can be most beautifully expressed by using a certain language'. On the other hand, reacting to a post or replying with a comment is determined by the original language of the shared content or by the nationality of the user: even if he gets a birthday wish in English from a Romanian friend, he will reply in Romanian, out of respect.

He disapproves spelling mistakes, considers himself a grammar náci 'grammar Nazi', and with this deliberate code-mixing he wants to highlight his attitude. His attitude towards code-switching and mixing is rather negative, only added connotation can justify their use: Ha többletértelmet hordoz a kavarás, akkor teljesen rendben van. 'If mixing (words) carries further connotations, then it is OK.' However, during the interview, he often mixes English phrases and words with Hungarian ones. On Adam's Facebook account, code play and code-switching take place in discourses in which the actors know each other quite well. These linguistic practices occur when humour is involved, and mixing languages within a comment carries further connotations. Multimodality and intertextuality are also common features on Facebook: he may choose a Romanian text for photos, memes, or songs, especially if they deliver a humorous message or express an inside joke (as phrased by Adam).

The post (Figure 3) with the Hungarian caption Szalagavatónk! 'Our graduation ceremony!' is commented in Romanian: Ai de viata mea! 'Oh, my life!', and it refers to a Romanian YouTuber, being the relocalization of a quote, used as a translocal opportunity to connect to a more global and multilingual world.

Here, the process of working with different languages should be understood as translingual practice because it makes its meaning through "the context of transnational lingua-cultural flow" (Dovchin 2020: 58). Adam also shares memes in English, which is a newly found habit of his, as many of his university colleagues speak English, and therefore he feels relaxed to use English, which creates a global context. Sharing memes in Romanian is also convenient as Adam is convinced that those who have to understand the message will get it, and he can expand his audience group by using more languages. According to him, there are certain rules that he follows. First of all, code-switching is possible and accepted if it happens among friends and reflects some humorous content or refers to an inside joke, which carries a particular message for the agents of the communicative situation. Any code play, however, is connected to a global context, and Adam's Facebook account serves as a translocal space where local and global connect. These practices and language choices are examples of translingual practices, and linguistic resources are exploited to create meaning. 


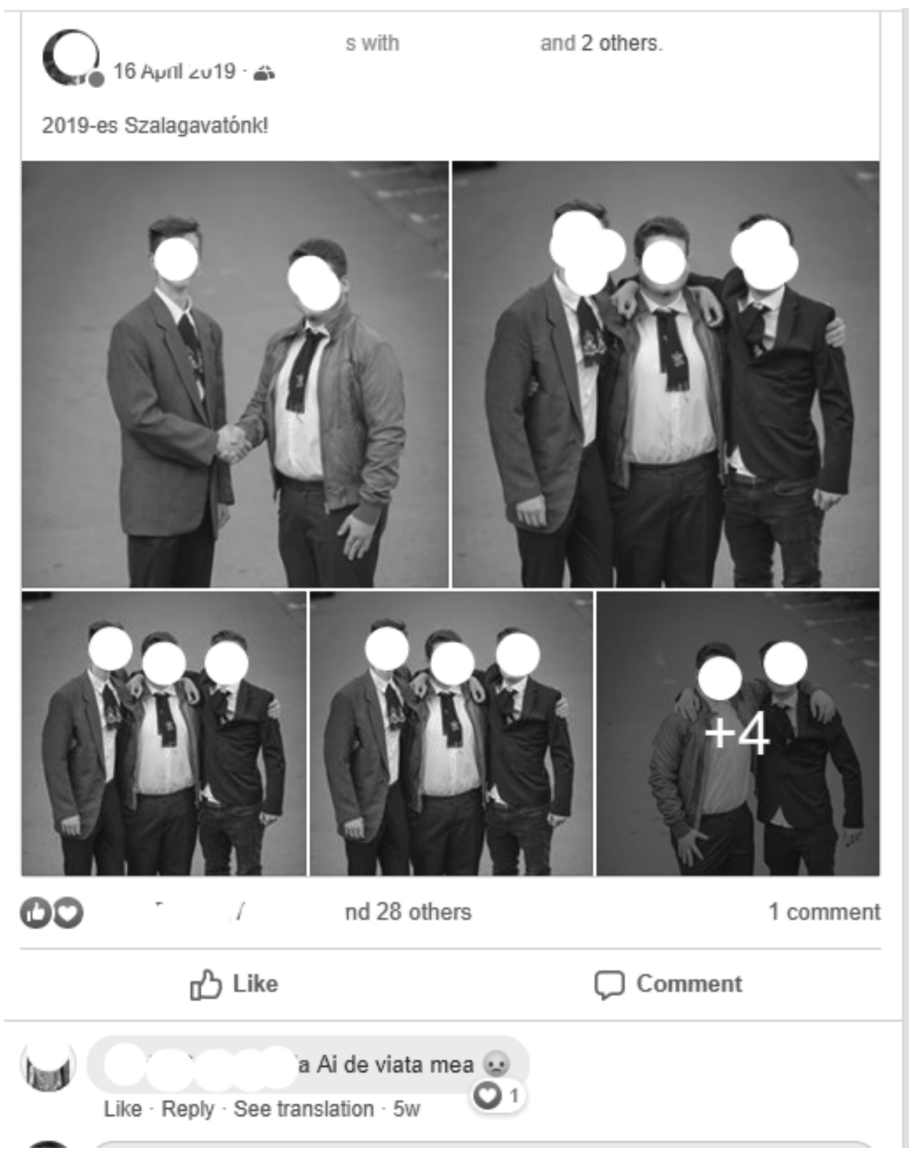

Figure 3. Code play as inside joke

\subsection{Participant B}

Participant B (reference name: Béla, male, Sapientia $2^{\text {nd }}$-year student, majoring in translation-interpreting) also presents online code-switching and translingual practices, which refer to relocalization of English, French, and other semiotic resources integrated within Hungarian and Romanian. His literacy practices represent offline aspects of his linguistic identity.

The second interview participant comes from a Hungarian family; his mother tongue (L1) is Hungarian. He lives with his mother in a small town, where 30 per cent of the population is Hungarian, while the majority of the population is Romanian. He started learning Romanian in his early childhood, and he speaks it on a daily basis. Time and again, he struggles to find the appropriate Hungarian words. He personally experienced the advantages and disadvantages of living in a bilingual community at a very early age, and he preferred choosing Romanian over Hungarian 
in everyday situations when he had to address unfamiliar individuals. Béla is fond of languages: he speaks English, a little German, and he has been learning French on his own (proven by his French-language textbook during the interview), also due to the fact that he has some relatives living in France. He believes that songs, poems sound more attractive in their original language; and with their translation something valuable is lost.

\subsubsection{Béla's choice of languages online: "I always pay attention to my choice of languages"}

In the online space, different default languages are installed on his electronic devices. For example, the default language of his computer is English. Hungarian is the default language of his laptop, while English is set on his phone. He plays a lot of video games, and being in multiplayer video games he encountered several languages (English, French, German, Spanish, and Chinese). However, the influence of the English is obvious in those settings, and it is accepted to mix languages during video games or in comments.

Regarding Facebook, which he started to use several years ago, the choice of the language depends on the partner he communicates with. Sharing something in Romanian is handy, understood by almost everyone in Transylvania. Béla does not have any friends from Hungary, and therefore he does not share anything exclusively in Hungarian. An interesting remark of his emphasizes his metalinguistic awareness: mindig odafigyelek, melyik nyelvet használjam 'I always consider my choice of languages'. As he mentions, English is the lingua franca, the neutral language of communication on Facebook. He would like to stay neutral, not to fall for any language ideology. He does not want to highlight the dominance of either language: Hungarian or Romanian. According to him, addressing a wider audience requires the choice of English even if none of the participants in the discourse is English.

On the other hand, the choice of the language is determined by the media content as well: translations deprive texts of their originality. Similar to Adam, he respects the linguistic identity of his partner in the discourse; the reaction is determined by the original language of the shared content or by the nationality of the user. Choosing a different language has humorous connotations. He posted the caption: Je ne parle pas français 'I do not speak French', which was a deliberate act to convey humour and deliver a joke at the same time, a global content in a translocal space. In this translocal space, code play becomes a common multilingual practice (Figure 4). 


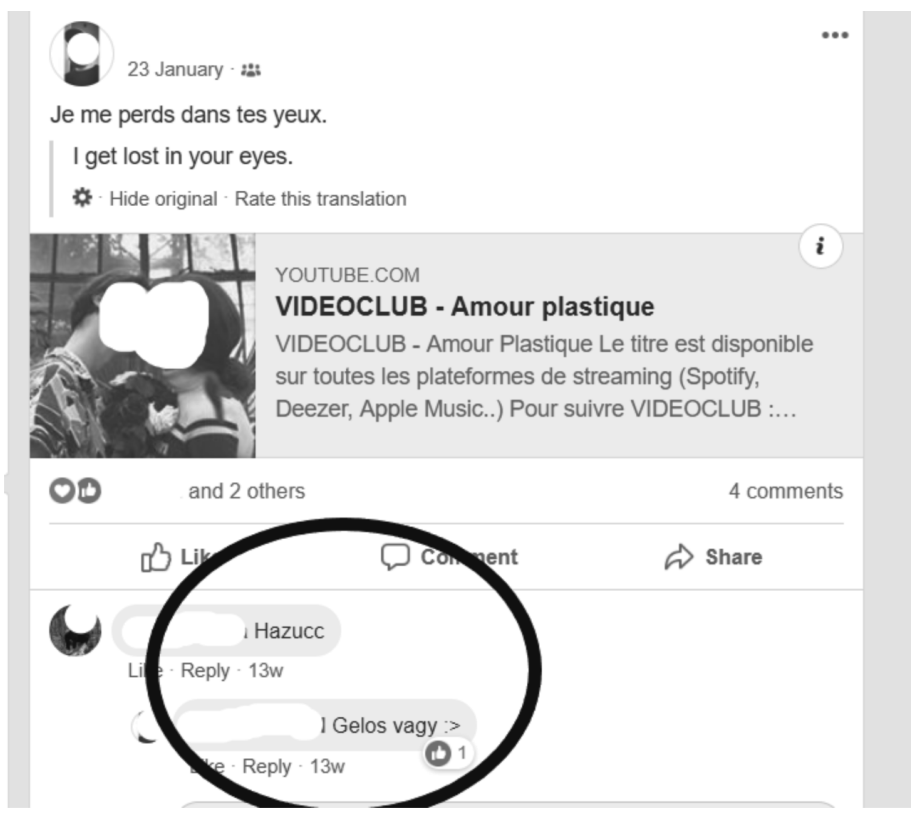

Figure 4. Code play and multilingual creativity

Participant B mixes languages within the same post: French, English, Romanian, and Hungarian. The relocalization of a French song with the English translation constructs his global identity, while the code play used in the comments establishes the local reference. The Hungarian comment Hazucc 'You are lying' is followed by a code play (Romanian and Hungarian): Gelos vagy 'You are jealous'. The spelling mistake of the Hungarian word (the word is written incorrectly, with a double $c$ ) turns out to be an invitation for an inside joke, according to the metadata of the interview. Thus, the participant creatively combines the two languages, replying to the Hungarian comment in the same language (Hungarian) but mixing it with Romanian, with the language the user also identifies with.

Another local content with a humorous reference is created by the following code play (Figure 5), which not only marks the linguistic identity of the user but also creates permissive linguistic behaviour and creativity in the digital space. The participant ingeniously uses Romanian with English to give a greater impact to the message. It can be seen as a source of humour expressed by code-switching; however, the embedded Romanian word grătar creates the local reference: Waiting for the grătar 'Waiting for the barbecue'. The linguistic creativity establishes a global content and eases communication between the agents in the discourse, and, again, it makes its meaning through the transnational stream of languages. 
25 April

Waiting for the grătar

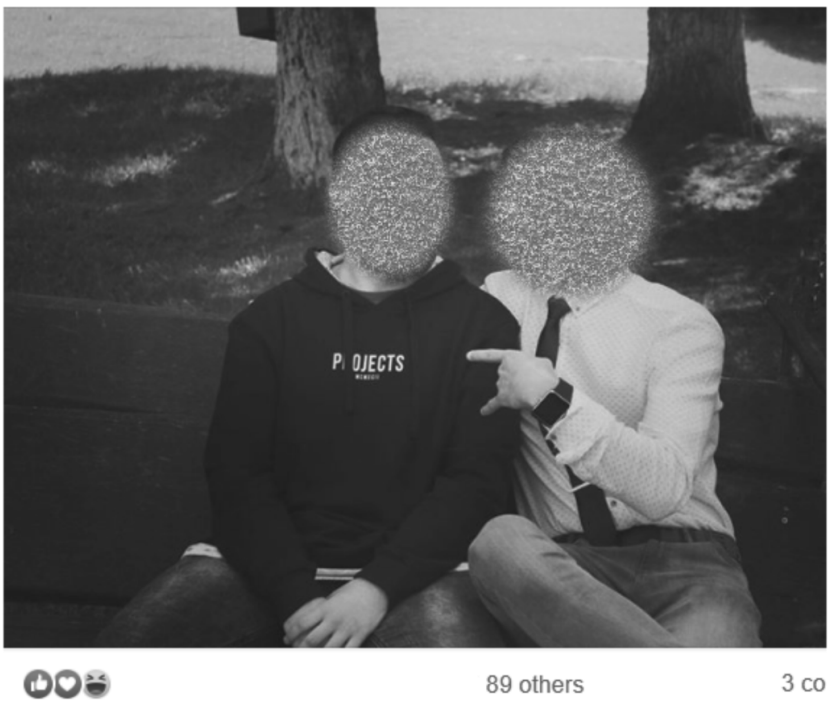

Share

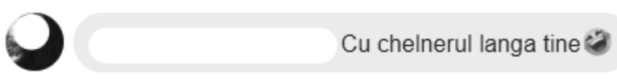

Figure 5. Code play as inside joke

With the inside joke ( $\mathrm{Cu}$ chelnerul lângă tine 'With the waiter next to you'), the whole communication is personalized, and, according to the participant, the code play here serves a further role: a neutral code is mixed with a non-neutral one, which turns code-switching into translanguaging, also creating a translocal space for the partners. Similarly, the use of English slang words, embedded in local contexts, is very intense. As Participant B explains, the word "cringe" has become a very popular one, referring to something very undesirable. In this case, it eases communication and shifts this linguistic practice towards a translingual one.

\section{Conclusions}

This paper has explored how online engagement in everyday digital literacy practices through social media, such as Facebook, is a product of the multilingual practices in the digital space. Although the participants have a shared language in their online language setting, they choose other languages either to add further communicative references and connotations or as an additional resource to establish better understanding and comprehension of communicative goals. Their 
motivations for language choice can vary a great deal. Sometimes, it is the extension of their bi- or multilingual language practices offline, but it can also be an outcome of a peer- or group-specific language policy, specific to online communication. The examples have shown how the digital linguistic practices of these Facebook users deploy an array of interconnected linguistic (Hungarian, Romanian, English, French, etc.), semiotic, and cultural resources (posting hyperlinks, illustrations and images, captions, comments, etc.). On the other hand, the online linguistic identities of these participants are also interconnected with their offline linguistic repertoires. The online and offline spaces in which these young adults interact are complexly conjoined, with meanings, resources, and identities crossing over from one space to the other, from local to translocal and finally global. By showing these creative online digital literacy practices, such as code play, the notions of codeswitching and translanguaging are extended beyond the notion of multilingualism as Facebook users perform these linguistic practices to stay local and to become global at the same time. Online digital linguistic practices may provide richer multilingual and multimodal resources than offline lives, and offline identities are filtered through their online literacy activities from code-switching to translanguaging. It is thus important to consider social network sites as part of broader systems of linguistic practices, which in turn can be a useful way to understand how online/ offline linguistic identities are interrelated. The use of multiple languages does not necessarily represent a certain (linguistic) identity; it rather acts as a tool or strategy to express translocal or global identities and grants a certain linguistic freedom, which indicates new possibilities of meaning-making in the digital space.

\section{References}

Androutsopoulos, Jannis. 2006. Introduction: Sociolinguistics and computermediated communication. Journal of Sociolinguistics 10(4): 419-438.

- 2007. Bilingualism in the mass media and on the Internet. In Monica Heller (ed.), Bilingualism: A Social Approach, 207-232. New York: Palgrave Macmillan.

Blommaert, Jan-Ben Rampton. 2011. Language and superdiversity. Diversities 13(2): 3-21.

Canagarajah, Suresh. 2013. Negotiating translingual literacy: An enactment. Research in the Teaching of English 48(1): 40-67.

de Bres, Julia. 2015. Introduction: Language policies on social network sites. Language Policy 14(4): 309-314.

Dovchin, Sender. 2020. Translingual English, Facebook and gay identities. World Englishes 39: 54-66. 
Dovchin, Sender-Alastair Pennycook. 2018. Digital metroliteracies: Space, diversity, and identity. In Kathy Mills-Amy Stornaiuolo-Anna Smith-Jessica Z. Pandya (eds), Handbook of Digital Writing and Literacies in Education, 211-223. New York: Routledge.

García, Ofelia-Wei Li. 2014. Translanguaging: Language, Bilingualism and Education. Basingstoke: Palgrave Macmillan.

Kozinets, Robert. 2006. Netnography 2.0. In Russel W. Belk (ed.), Handbook of Qualitative Research Methods in Marketing, 129-142. Edward Elgar, Cheltenham.

Lee, Carmen. 2016. Multilingualism Online. London: Routledge.

Leppänen, Sirpa-Janus Møller-Thomas Nørreby-Andreas Stæhr-Samu Kytöla. 2015. Authenticity, normativity and social media. Discourse, Context and Media 8: $1-5$.

Leppänen, Sirpa-Saija Peuronen. 2012. Multilingualism on the Internet. In Marilyn Martin-Jones-Adrian Blackledge-Angela Creese (eds), Handbook of Multilingualism, 384-402. London: Routledge.

$\mathrm{Li}$, Wei. 2016. New Chinglish and the Post-Multilingualism Challenge: Translanguaging ELF in China. Journal of English as a Lingua Franca 5(1): 1-26.

Pennycook, Alastair. 2016. Mobile times, mobile terms: The trans-super-poly-metro movement. In Nicolas Coupland (ed.), Sociolinguistics: Theoretical Debates, 201-216. Cambridge: Cambridge University Press.

Peuronen, Saija. 2011. 'Ride Hard, Live Forever': Translocal identities in an online community of extreme sports Christians. In Crispin Thurlow-Kristine Mroczek (eds), Digital Discourse. Language in the New Media, 154-176. Oxford: Oxford University Press.

Sharma, Bal Krishna. 2012. Beyond social networking: Performing global Englishes in Facebook by college youth in Nepal. Journal of Sociolinguistics 16(4): 483-509. Skutnabb-Kangas, Tove-Teresa McCarty. 2008. Key concepts in bilingual education: Ideological, historical, epistemological, and empirical foundations. In Jim Cummins-Nancy Hornberger (eds), Language Policy and Political Issues in Education, Vol. 1, Encyclopedia of Language and Education, 3-17. $2^{\text {nd }}$ edition, New York: Springer.

Thurlow, Crispin. 2012. Determined creativity: Language play, vernacular literacy and new media discourse. In Jones Rodney H. (ed.), Discourse and Creativity, 169-190. London: Pearson. 